\title{
Reelin Depletion in the Entorhinal Cortex of Human Amyloid Precursor Protein Transgenic Mice and Humans with Alzheimer's Disease
}

\author{
Jeannie Chin, ${ }^{1,2 \star}$ Catherine M. Massaro, ${ }^{3 \star}$ Jorge J. Palop, ${ }^{1,2}$ Myo T. Thwin, ${ }^{1}$ Gui-Qiu Yu, ${ }^{1}$ Nga Bien-Ly, ${ }^{1}$ Aaron Bender, ${ }^{1}$ \\ and Lennart Mucke ${ }^{1,2,3}$ \\ ${ }^{1}$ Gladstone Institute of Neurological Disease, ${ }^{2}$ Department of Neurology, and ${ }^{3}$ Neuroscience Graduate Program, University of California, San Francisco, San \\ Francisco, California 94158
}

\begin{abstract}
Reelin regulates nervous system development and modulates synaptic plasticity in the adult brain. Several findings suggest that alterations in Reelin signaling may contribute to neuronal dysfunction associated with Alzheimer's disease (AD). Cell surface receptors for Reelin, including integrins and very-low-density lipoprotein receptor/apolipoprotein E2 receptor, may be targets of amyloid- $\beta$ (A $\beta$ ) peptides presumed to play key roles in the pathogenesis of AD. Reelin also regulates the extent of tau phosphorylation. Finally, increased amounts of Reelin fragments have been found in CSF from AD patients, suggesting altered processing of Reelin. We therefore hypothesized that Reelin levels might be altered in the brains of human amyloid precursor protein (hAPP) transgenic mice, particularly in brain regions vulnerable to AD such as hippocampus and entorhinal cortex. Compared with nontransgenic controls, hAPP mice had significantly fewer Reelin-expressing pyramidal cells in the entorhinal cortex, the major population of glutamatergic neurons expressing Reelin in the brain. Western blot analysis of the hippocampus, which receives projections from the entorhinal cortex, revealed significant reductions in Reelin levels. In contrast, the number of Reelin-expressing GABAergic interneurons was not altered in either the entorhinal cortex or the hippocampus. Thus, neuronal expression of hAPP/A $\beta$ is sufficient to reduce Reelin expression in a specific population of entorhinal cortical pyramidal neurons in vivo. Underscoring the relevance of these findings, we found qualitatively similar reductions of Reelin-expressing pyramidal neurons in the entorhinal cortex of AD brains. We conclude that alterations in Reelin processing or signaling may be involved in AD-related neuronal dysfunction.
\end{abstract}

Key words: Alzheimer's disease; plasticity; hippocampus; signaling; extracellular matrix; neurotransmission

\section{Introduction}

Although the precise cellular and molecular mechanisms underlying Alzheimer's disease $(\mathrm{AD})$ remain to be defined, a great deal of evidence suggests that the human amyloid precursor protein (hAPP) and hAPP-derived amyloid- $\beta(\mathrm{A} \beta)$ peptides play central roles in its pathogenesis (Tanzi and Bertram, 2005). Oligomeric assemblies of $\mathrm{A} \beta$ can impair synaptic functions directly by blocking or aberrantly stimulating receptors or indirectly by affecting the levels of other proteins that maintain or enhance synaptic plasticity (Verdier et al., 2004; Walsh and Selkoe, 2004; Townsend et al., 2006). Signaling pathways that might contribute

\footnotetext{
Received Aug. 29, 2006; revised Jan. 31, 2007; accepted Feb. 6, 2007.

This study was supported by fellowships from the McBean Foundation (J.C., J.J.P.), National Institutes of Health (NIH) Grants NS041787, AG022074, and AG023501 (L.M.), and a facilities grant (RR018928) from the NIH National Center for Research Resources. We thankX. Wang and H. Ordanza for technical assistance, and D. Murray McPherson for administrative assistance. We thank Drs. J. P. Vonsattel and L. S. Honig for human brain tissue and clinical/ pathological data from the Alzheimer's Disease Research Center and New York Brain Bank at Columbia University Medical Center (supported by National Institutes of Health Grants P50AG008702 and P01AG007232).

*J.C. and C.M.M. contributed equally to this work.

Correspondence should be addressed to Dr. Lennart Mucke, 1650 0wens Street, San Francisco, CA 94158. E-mail: Imucke@gladstone.ucsf.edu.

DOI:10.1523/JNEUROSCI.3758-06.2007

Copyright $\odot 2007$ Society for Neuroscience $\quad 0270-6474 / 07 / 272727-07 \$ 15.00 / 0$
}

to $\mathrm{A} \beta$-induced impairments of synaptic plasticity include the Reelin pathway.

Reelin is a glycoprotein of the extracellular matrix whose levels are altered in the CSF and cortex of AD patients (Saez-Valero et al., 2003; Botella-López et al., 2006). During development, Reelin is involved in neuronal migration and positioning (Tissir and Goffinet, 2003). In the mature brain, it modulates neuronal function and synaptic plasticity and regulates tau phosphorylation as well as axonal growth and dendritic spine morphology (Hiesberger et al., 1999; Liu et al., 2001; Fatemi, 2005; Herz and Chen, 2006; Qiu et al., 2006). Reelin also enhances the induction of long-term potentiation (LTP), likely related to its effects on NMDA receptor function (Weeber et al., 2002; Beffert et al., 2005; Chen et al., 2005) and its ability to stimulate the translation of dendritically expressed transcripts, such as the mRNA encoding activity-regulated cytoskeletal protein Arc (Dong et al., 2003).

In most of the brain, Reelin is expressed by GABAergic interneurons that locally regulate the activity and function of neighboring glutamatergic neurons (Pesold et al., 1998; RamosMoreno et al., 2006). Interestingly, Reelin is also expressed by glutamatergic pyramidal neurons in layer II of the rodent entorhinal cortex (Pesold et al., 1998; Ramos-Moreno et al., 2006), a population of neurons affected early and severely by AD (Blen- 
now et al., 2006). These neurons project primarily to the dentate gyrus and CA1 of the hippocampus (van Groen et al., 2003; Ramos-Moreno et al., 2006), which is also very vulnerable to $\mathrm{AD}$ (Blennow et al., 2006). Although Reelin does not appear to undergo calcium-dependent exocytosis (Lacor et al., 2000), its localization in secretory vesicles, axons, and dendritic spine-rich neuropils suggests that it may be released from both the cell soma and synaptic terminals (Pesold et al., 1998; Lacor et al., 2000; Pappas et al., 2001; RamosMoreno et al., 2006). Reelin immunoreactivity is also present in axonal projections of glutamatergic pyramidal neurons in layer II of the entorhinal cortex (RamosMoreno et al., 2006), suggesting that Reelin produced by these cells is transported down axons and may impact neuronal function in target regions such as the dentate gyrus and CA1.

The ability of Reelin to modulate neuronal and synaptic functions, together with its pattern of localization, suggests that alterations in Reelin or related signaling pathways may play a role in the pathogenesis of $\mathrm{A} \beta$-induced neurological decline. To test this hypothesis, we examined the levels and distribution of Reelin in brains of hAPP transgenic mice that have $\mathrm{A} \beta$-dependent synaptic and behavioral deficits.

\section{Materials and Methods}

Transgenic mice and human brain tissues. hAPP transgenic line J20 produces hAPP carrying the Swedish (K670N, M671L) and Indiana (V717F) familial AD (FAD) mutations (hAPP770 numbering); line I5 produces wild-type hAPP $\left(\mathrm{hAPP}_{\mathrm{WT}}\right)$ at comparable levels. Transgene expression in both lines is directed by the plateletderived growth factor $\beta$ chain promoter (Rockenstein et al., 1995; Mucke et al., 2000). The lines had been crossed for $>10$ generations onto a C57BL/6 background using nontransgenic mice from The Jackson Laboratory (Bar Harbor, ME). Unless indicated otherwise, mice were evaluated at 6-8 months of age. Mice were anesthetized and flush perfused transcardially with PBS. Hemibrains were fixed in $4 \%$ phosphate-buffered paraformaldehyde or stored at $-70^{\circ} \mathrm{C}$. All experiments were approved by the Institutional Animal Care and Use Committee of the University of California, San Francisco.

Frozen blocks of human postmortem tissue containing entorhinal cortex from $\mathrm{AD}$ cases and nondemented controls were obtained from the Alzheimer's Disease Research Center and New York Brain Bank at Columbia University Medical Center. Tissue blocks were thawed and fixed in $4 \%$ phosphate-buffered paraformaldehyde for $48 \mathrm{~h}$.

Immunohistochemistry. For mouse brain sections, sliding microtome sections $(30 \mu \mathrm{m})$ were avidin-biotin/immunoperoxidase stained using an anti-Reelin antibody (clone G10; Millipore, Bedford, MA) followed by biotinylated donkey anti-mouse (1:200; Vector Laboratories, Burlin-

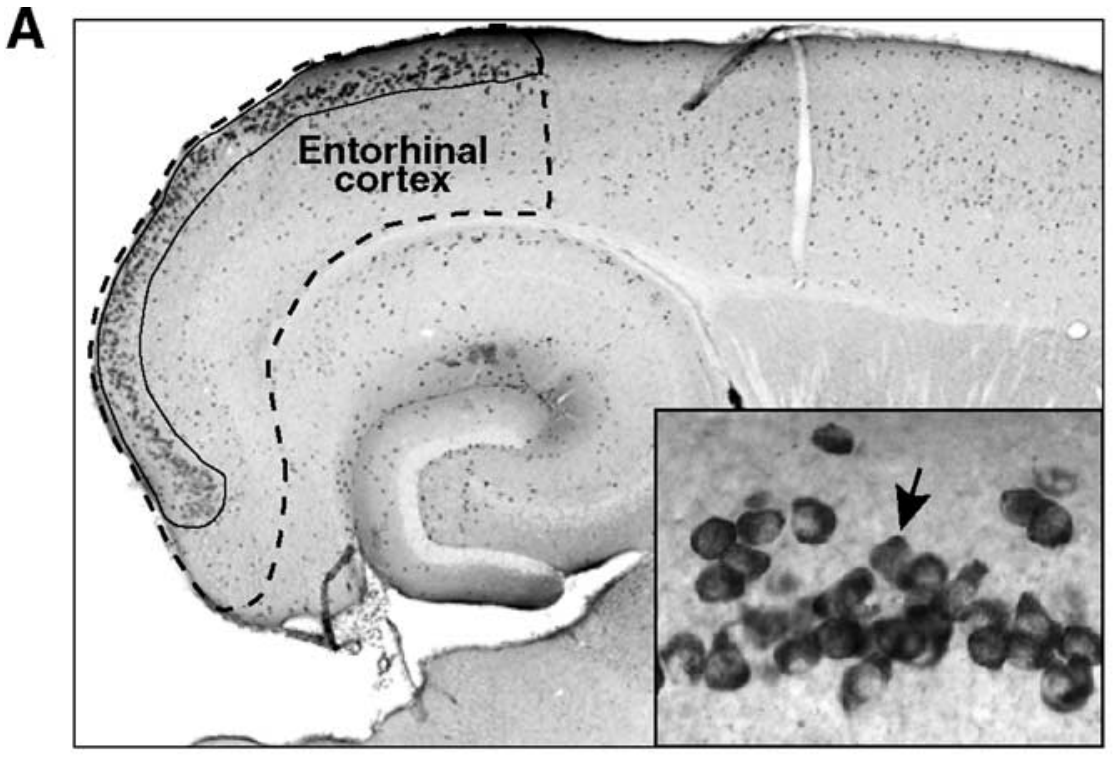

B
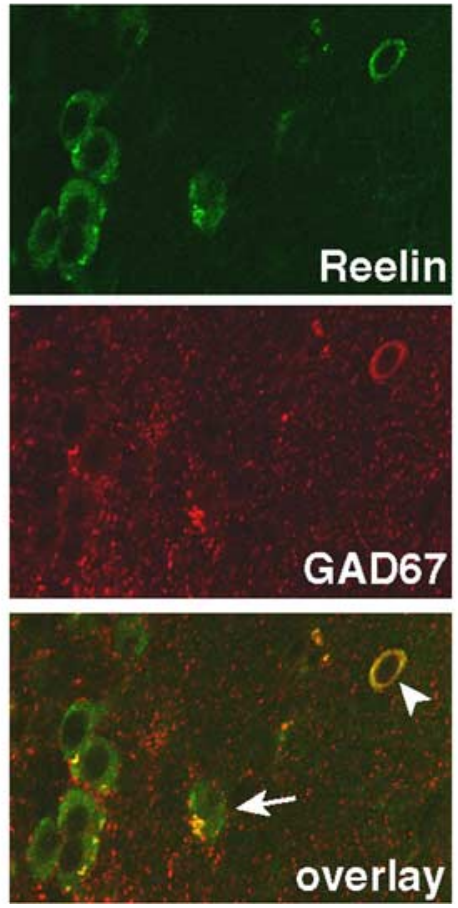

Figure 1. Two populations of neurons in the mouse entorhinal cortex express Reelin. A, Low-magnification view of a horizontal brain section from a nontransgenic mouse immunostained for Reelin. The stippled line delineates the entorhinal cortex and the solid line the population of pyramidal neurons in layer II that express Reelin. Inset, High-magnification view of layer II of the entorhinal cortex. Arrow points to a Reelin-expressing pyramidal neuron. B, C, Double immunostaining for Reelin (green) and for GAD67 (red), a marker of GABAergic neurons. Overlay in $\boldsymbol{B}$ demonstrates that Reelin is expressed by glutamatergic pyramidal neurons (arrow) and by GABAergic interneurons (arrowhead). Overlay in C illustrates the presence of GAD67-positive terminals (arrows) surrounding the cell body of a Reelin-positive pyramidal cell. game, $\mathrm{CA}$ ) as the secondary antibody. Diaminobenzidine was used as the chromagen. For fluorescence immunohistochemistry, the following primary antibodies were used: anti-Reelin (1:100), anti-GAD67 (1:1000; Millipore), anti-Disabled 1 (Dab1) (Millipore), and anti-microtubuleassociated protein 2 (MAP2) (1:100; Millipore). Fluorescein-labeled donkey anti-mouse (1:300; Jackson ImmunoResearch, West Grove, PA) and Texas Red-labeled goat anti-rabbit (1:300; Jackson ImmunoResearch) were used as secondary antibodies. Immunofluorescence was visualized by confocal microscopy (Radiance 2000; Bio-Rad, Hercules, CA). Each group of mice (transgenic line and age) was processed as an independent experi- 
A
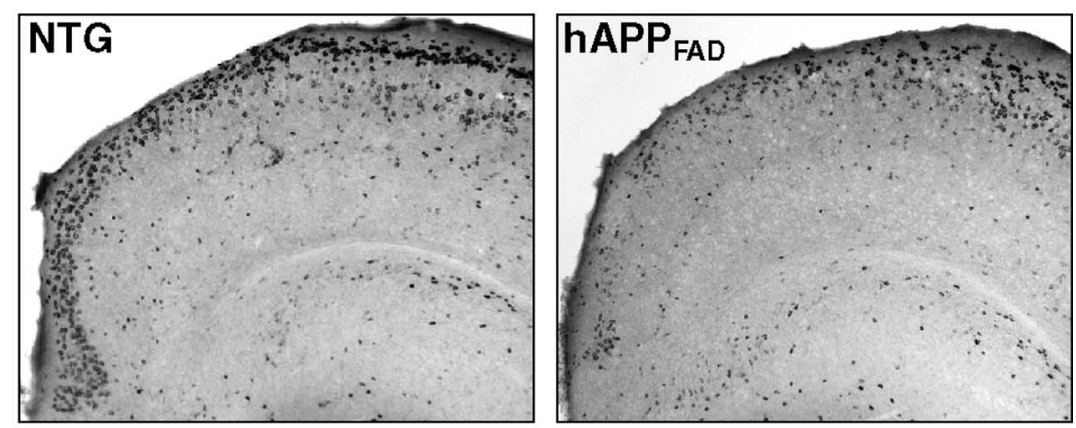

B

6-7 months

12-16 months
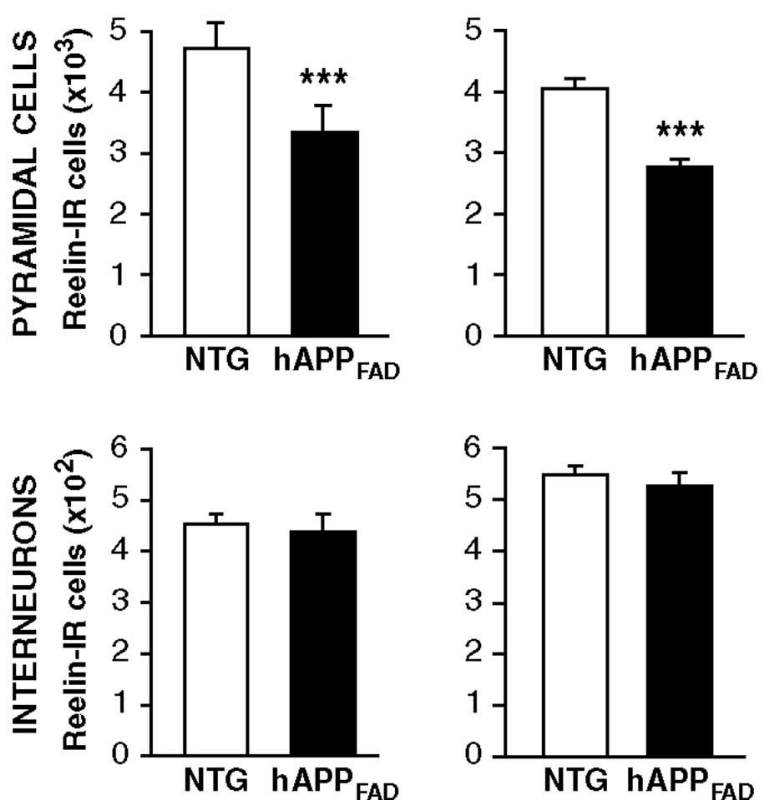

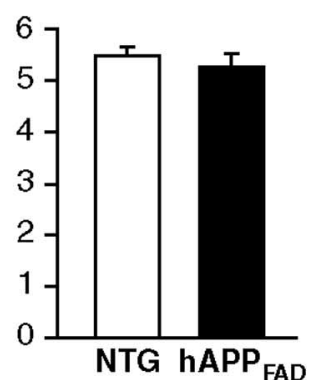

12-16 months
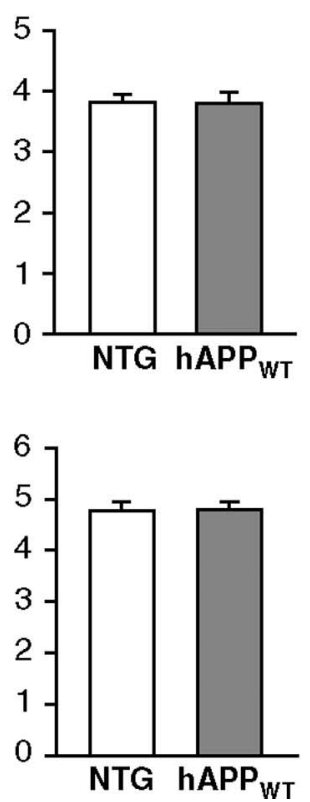

7.4, 10 mм EDTA, 10 mm EGTA, 1\% deoxycholate, $1 \mathrm{~mm}$ PMSF, phosphatase inhibitor cocktails I and II (Sigma, St. Louis, MO), and protease inhibitor cocktail (Roche, Indianapolis, IN). Samples were then briefly sonicated on ice and centrifuged at $5000 \times g$ for $10 \mathrm{~min}$. Equal amounts of protein (determined by Bradford assay) were resolved by SDS-PAGE on $4-12 \%$ gradient gels and transferred to nitrocellulose membranes. Membranes were probed with anti-Reelin antibody (1:1000), followed by incubation with HRP-conjugated goat antimouse IgG (1:10,000; Millipore) as secondary antibody. Bands were visualized by ECL and quantitated densitometrically with Quantity One 4.0 software (Bio-Rad).

For quantitative fluorogenic reverse transcription (RT)-PCR, RT reactions contained 150 ng of total RNA (DNase-treated) and random hexamer plus oligo-dT primers. Diluted reactions were analyzed with SYBR green PCR reagents and an ABI Prism 7700 sequence detector (Applied Biosystems, Foster City, CA). cDNA levels of Reelin, synaptophysin, and calbindin were determined relative to standard curves from pooled samples. The slope of standard curves, control reactions without RT, and dissociation curves of products indicated adequate PCR quality. Primer sequences were as follows: Reelin, 5'-AAGCTTTGGCAGTGCCAGACT-3', 5'-AAAGGACGTGATTAGCTGCCG-3'; synaptophysin, 5'-GTTGGGAGCTGTGAGGTGAGTT-3', 5'-GGGAGTCAGTAAGGGACAT-TTCG 3'; and calbindin, 5'-GGAAAGGAGCTGCAGAACTTGAT-3', 5' '-TTCCGGTGATAGCTCCAATCC-3'.

Statistical analyses. Statistical analyses were performed with Statview 5.0 (SAS Institute, Cary, NC). Differences between means were assessed by Student's $t$ test.

Figure 2. The number of Reelin-expressing pyramidal cells in the entorhinal cortex is decreased in hAPP ${ }_{F A D}$ mice. $\boldsymbol{A}$, Horizontal sections from nontransgenic (NTG) controls and hAPP ${ }_{F A D}$ mice illustrating Reelin immunoreactivity. $\boldsymbol{B}$, Reelin-positive cells were counted in every 10th section throughout the dorsoventral extent of the entorhinal cortex. hAPP FAD mice (black bars) had a significant reduction in Reelin-IR pyramidal cells, but not interneurons, at $6-7$ (left) and 12-16 (middle) months of age ( $n=$ $10-14$ mice per genotype and age). In contrast, hAPP ${ }_{\mathrm{WT}}$ mice (gray bars; $n=7-8$ mice per genotype) did not differ from nontransgenic controls in Reelin-IR pyramidal cells or interneurons (right). ${ }^{* * *} p<0.001$ versus nontransgenic.

\section{Results}

Reelin is expressed in two populations of cells in the mouse entorhinal cortex Although the majority of Reelinexpressing neurons in the cortex are GABAergic interneurons, glutamatergic pyramidal neurons in layer II of the ento-

ment. Nontransgenic and hAPP mice within each age group were processed simultaneously. Numbers of Reelin-immunoreactive (IR) neurons were determined by counting labeled cells in layer II of the entorhinal cortex in every 10th serial horizontal section throughout the dorsoventral extent of the entorhinal cortex.

For human brain sections, sliding microtome sections $(60 \mu \mathrm{m})$ were subjected to antigen retrieval (incubation in citrate buffer, $\mathrm{pH} 6$ ) and treatment with $90 \%$ formic acid before incubation with anti-Reelin antibody (mAb 142; Millipore) and then with biotinylated donkey antimouse (1:200; Vector Laboratories) as secondary antibody. Diaminobenzidine was used as the chromagen. For cresyl violet staining, sections were mounted on glass slides and incubated in $0.5 \%$ cresyl violet solution. After clearing of excess solution in $70 \%$ ethanol with $0.1 \%$ acetic acid, sections were dehydrated with an ethanol series and incubated in xylenes.

Western blot and quantitative fluorogenic reverse transcription-PCR. A McIlwain tissue chopper was used to cut mouse hemibrains into 450$\mu \mathrm{m}$-thick horizontal sections from which the dentate gyrus, CA1, and entorhinal cortex were microdissected on ice. For protein analysis, dentate gyrus or CA1 samples from each hemibrain were pooled and homogenized on ice in buffer containing $320 \mathrm{~mm}$ sucrose, $10 \mathrm{~mm}$ Tris- $\mathrm{HCl}, \mathrm{pH}$ rhinal cortex also express Reelin at high levels (Fig. 1A), consistent with previous findings (Pesold et al., 1998; Ramos-Moreno et al., 2006). Double labeling of cells for Reelin and for GAD67, a marker of GABAergic interneurons, demonstrated that the large pyramidal neurons in layer II of the entorhinal cortex express Reelin but not GAD67, whereas smaller neurons outside of the strip of large pyramidal neurons expressed both Reelin and GAD67 (Fig. 1 B). High-magnification micrographs illustrate the presence of GAD67-positive terminals surrounding the cell body of a Reelin-positive, GAD67-negative pyramidal cell (Fig. 1C, arrows).

The number of pyramidal cells expressing Reelin in the entorhinal cortex is decreased in $\mathrm{hAPP}_{\mathrm{FAD}}$ mice

$\mathrm{hAPP}_{\mathrm{FAD}}$ transgenic mice from line J20 have high levels of $\mathrm{A} \beta$ in the brain and show plaque-independent deficits in learning and memory that correlate tightly with alterations in synaptic activity-related signaling pathways in the dentate gyrus (Mucke et al., 2000; Palop et al., 2003, 2005; Chin et al., 2005). At 6 months 
of age, hAPP ${ }_{\text {FAD }}$ mice had an $~ 30 \%$ decrease in the number of Reelin-expressing pyramidal cells in layer II of the entorhinal cortex compared with nontransgenic controls (Fig. $2 A, B$ ), and none of the mice had plaques in the entorhinal cortex (data not shown). hAPP ${ }_{\mathrm{FAD}}$ mice had a similar decrease in Reelin-expressing pyramidal cells at $12-16$ months (Fig. $2 A, B$ ). In contrast, the number of smaller, nonpyramidal Reelin-expressing neurons, which most likely represent interneurons, was simi-

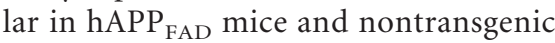
controls in both age groups (Fig. 2 B). No changes were found in the numbers of Reelin-expressing cells (pyramidal cells or interneurons) in the entorhinal cortex of 12- to 16-month-old hAPP ${ }_{\mathrm{WT}}$ mice (Fig. $2 B$ ).

The decrease in the number of Reelinexpressing pyramidal neurons in $\mathrm{hAPP}_{\mathrm{FAD}}$ mice likely reflects a decrease in Reelin expression rather than a loss of Reelinexpressing neurons, because we saw no overt neuronal loss in brain sections double labeled for Reelin and the general neuronal marker MAP2 (Fig. 3A). Quantitative fluorogenic RT-PCR analysis of entorhinal cortex lysates revealed lower Reelin mRNA levels in hAPP $\mathrm{FAD}_{\text {mice than }}$ nontransgenic controls (Fig. 3B, top). Levels of synaptophysin mRNA in the entorhinal cortex of hAPP $\mathrm{FAD}_{\mathrm{F}}$ mice were also decreased(Fig. $3 B$, middle), whereascalbindin mRNA levels were not (Fig. 3B, bottom), suggesting differential alterations in the expression of synaptic activity-related gene products.

\section{Reelin protein levels are decreased in the hippocampus of hAPP $_{\text {FAD }}$ mice}

Layer II pyramidal neurons of the entorhinal cortex project to the molecular layer of the dentate gyrus and the stratum lacunosum of area CA1 (van Groen et al., 2003). Reelin expressed by these neurons is found not only in their cell bodies but also appears to be transported down their axons and released at terminals in the dentate gyrus and stratum lacunosum, resulting in a diffuse pattern of Reelin immunoreactivity in these regions (RamosMoreno et al., 2006). We also observed this type of diffuse immunostaining for Reelin in the molecular layer of the dentate gyrus and the stratum lacunosum of CA1 (Fig. 1A). To determine whether Reelin levels are decreased in these regions in $\mathrm{hAPP}_{\mathrm{FAD}}$ mice, we compared lysates from the dentate gyrus or CA1 of $\mathrm{hAPP}_{\mathrm{FAD}}$ mice and nontransgenic controls by Western blot analysis with a monoclonal antibody (clone G10) that recognizes the $\mathrm{N}$-terminal region of Reelin (Fig. $4 A$ ). In both the dentate gyrus and CA1 (Fig. $4 B, C$ ), hAPP ${ }_{\mathrm{FAD}}$ mice had decreased levels of fulllength Reelin and of the $180 \mathrm{kDa}$ fragment that is produced by extracellular cleavage of secreted Reelin (Tissir and Goffinet, 2003). These findings suggest that $\mathrm{hAPP} / \mathrm{A} \beta$-induced reductions in Reelin expression by layer II pyramidal neurons in the entorhinal cortex may reduce the amount of Reelin that is released into specific subregions of the hippocampus.
B
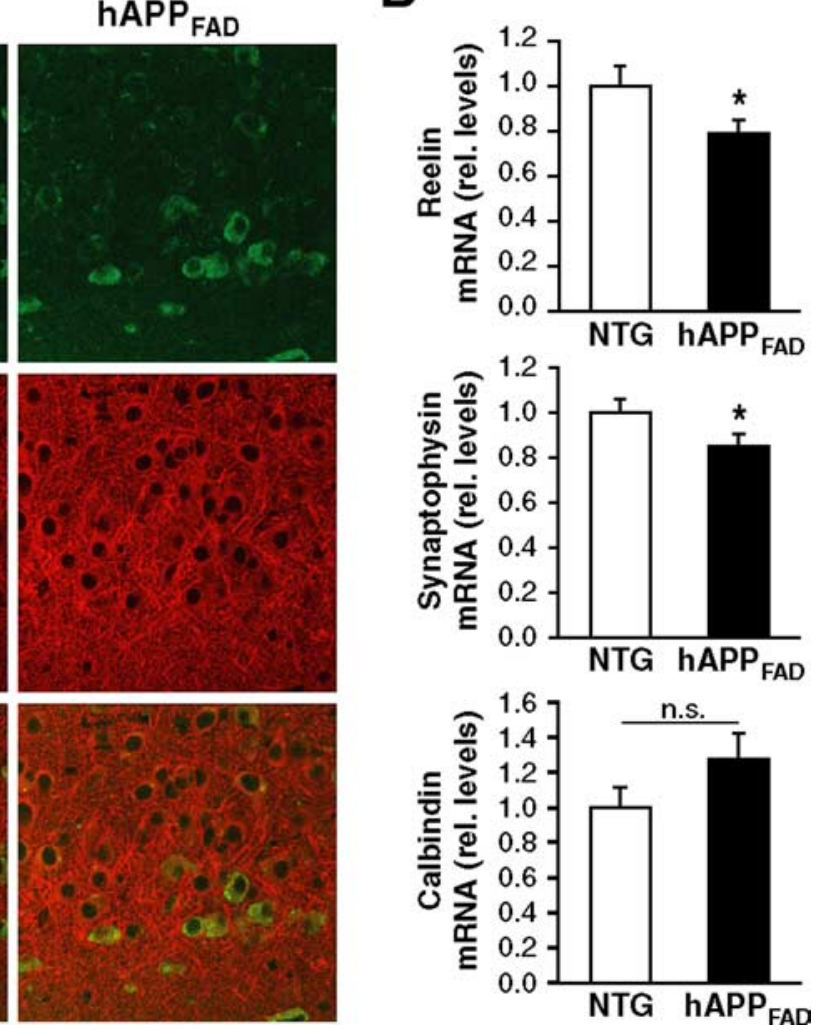

Figure 3. $h A P P_{F A D}$ mice have decreased levels of Reelin and synaptophysin mRNAs in the entorhinal cortex but no overt neuronal loss. A, Immunostaining of the entorhinal cortex for Reelin (green) and MAP2 (red) demonstrates comparable overall

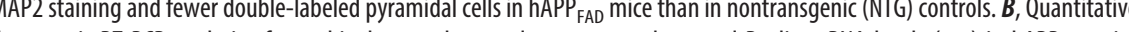
ive to nontransgenic controls. Although mRNA levels of other synaptically localized proteins such as synaptophysin were als
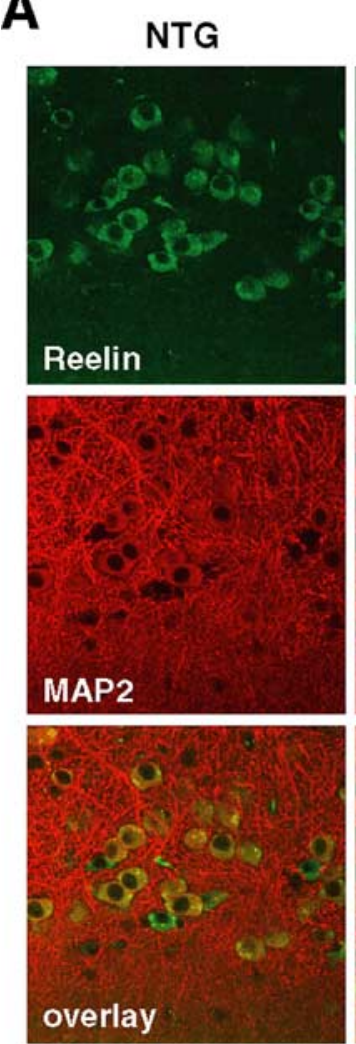

The number of pyramidal cells expressing Reelin in the entorhinal cortex is decreased in $\mathrm{AD}$ brains

Cajal-Retzius cells in layer I of the human entorhinal cortex express Reelin and are not altered in AD (Martin et al., 1999; Riedel et al., 2003). However, to our knowledge, neither Reelin expression in pyramidal neurons of layer II nor AD-related alterations in expression has been described in humans. Using a monoclonal antibody that recognizes human Reelin in tissue sections (Riedel et al., 2003), we found that human entorhinal pyramidal neurons in layer II also express Reelin (Fig. 5A). Reelin-expressing pyramidal neurons were grouped into "cell islands," reflecting the typical distribution of layer II pyramidal neurons in the human entorhinal cortex (Beall and Lewis, 1992; Insausti et al., 1995).

We also examined Reelin expression in sections from humans without dementia [clinical dementia rating (CDR) 0] or with moderate (CDR 2) to severe (CDR 3) autopsy-confirmed AD. Sections from the control group revealed normal Reelin expression in the entorhinal cortex (Fig. $5 B$, left column). In contrast, sections from $\mathrm{AD}$ patients exhibited fewer Reelin-positive layer II pyramidal neurons (Fig. 5B, middle and right columns). Cresyl violet staining indicated that a large proportion of the $\mathrm{AD}$-related reduction in Reelin-expressing neurons in the entorhinal cortex may be attributable to loss of pyramidal neurons, which has been documented previously (Gomez-Isla et al., 1996; Kordower et al., 2001; Morrison and Hof, 2002). However, we were able to detect cresyl violet-stained pyramidal neurons in CDR 3 samples, al- 
A Full-length Reelin

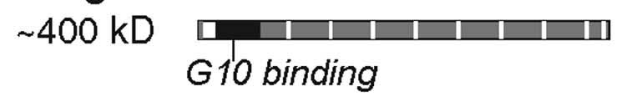

Proteolytic fragments
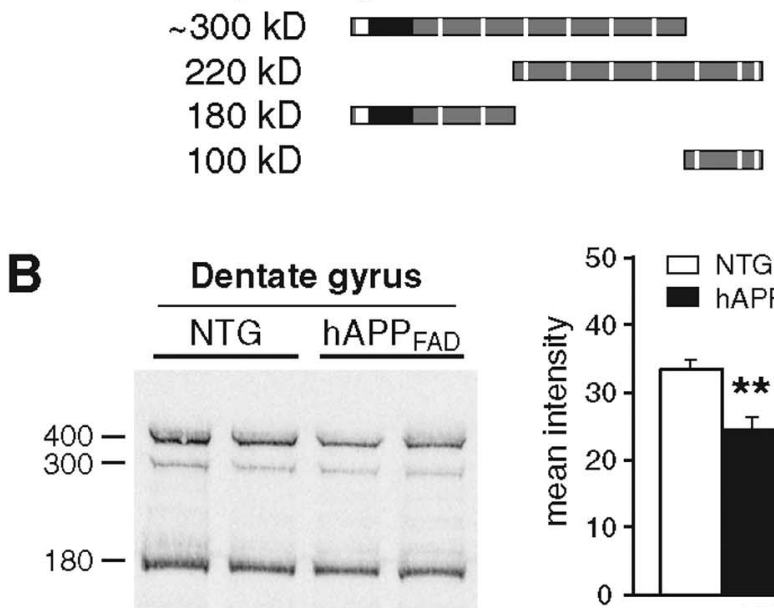

C

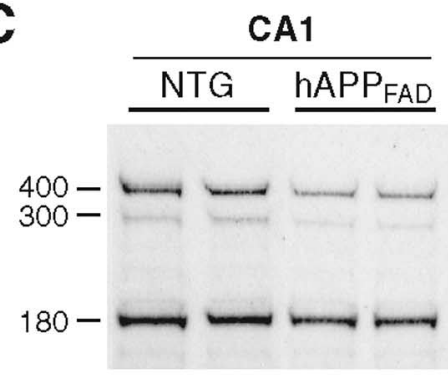

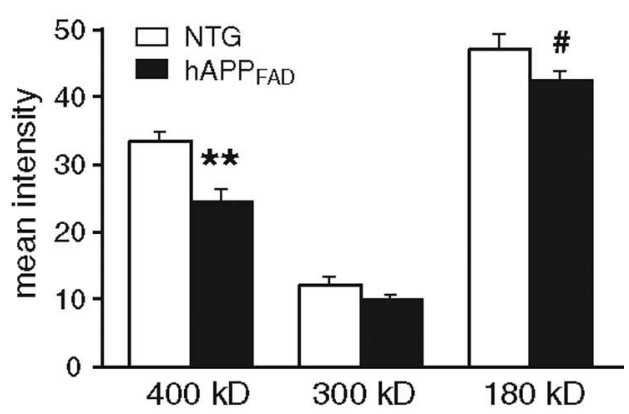

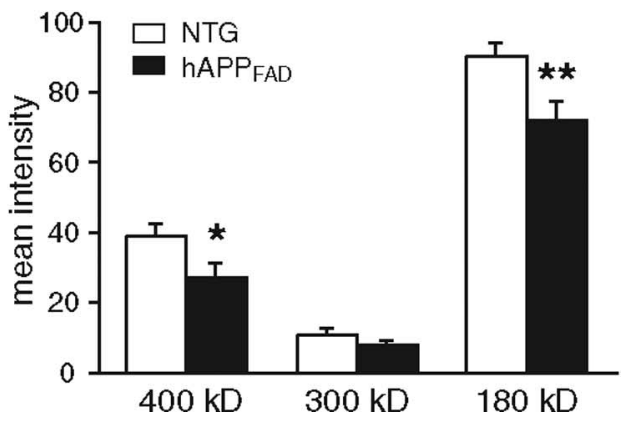

Figure 4. Reelin levels are decreased in the hippocampus of $\mathrm{hAPP}_{\mathrm{FAD}}$ mice. $\boldsymbol{A}$, Schematic illustrating full-length Reelin and the fragments produced by extracellular cleavage. Monoclonal antibody $\mathrm{G} 10$, used for both immunostaining and Western blot analyses, binds to Reelin where indicated. $\boldsymbol{B}, \boldsymbol{C}$, Western blot analysis of protein lysates from dentate gyrus $(\boldsymbol{B})$ or $C A 1(\boldsymbol{C})$ demonstrates a significant reduction in Reelin levels in $\mathrm{hAPP}_{\mathrm{FAD}}$ mice ( $n=10$ mice per genotype). Equal protein, determined by Bradford assay, was loaded in each lane. \#p $=0.06 ;{ }^{*} p<0.05 ;{ }^{* *} p<0.01$ versus nontransgenic (NTG).

though we did not observe any Reelin-expressing pyramidal neurons (Fig. 5B, right column).

\section{Discussion}

The current study demonstrates that neuronal expression of $\mathrm{hAPP} / \mathrm{A} \beta$ decreases the number of Reelin-expressing pyramidal neurons in layer II of the entorhinal cortex and reduces Reelin levels in hippocampal target regions of these neurons. Given the ability of Reelin to enhance synaptic plasticity (Weeber et al., 2002; Beffert et al., 2005; Chen et al., 2005), our results suggest that decreased levels of Reelin in these neurons could contribute to $\mathrm{AD}$-related impairments in memory and other cognitive functions. Indeed, we found that these neurons do express Reelin in the human entorhinal cortex. Moreover, these neurons lose Reelin expression and/or die in AD. Interestingly, Reelin levels in the frontal cortex, measured by Western blot analysis, are increased in AD (Botella-López et al., 2006). It is conceivable that the increased Reelin levels in the frontal cortex of $\mathrm{AD}$ brains reflect the kind of hyperactivation of frontal areas that is presumed to compensate for the failure of more vulnerable brain regions (Buckner, 2004; Pariente et al., 2005; Palop et al., 2006).

At 12-16 months, hAPP ${ }_{\mathrm{FAD}}$ mice had marked reductions in
Reelin-expressing pyramidal cells in the entorhinal cortex relative to nontransgenic controls, whereas hAPP ${ }_{\mathrm{WT}}$ mice did not (Fig. 2B). Because hAPP levels are comparable in $\mathrm{hAPP}_{\mathrm{FAD}}$ and $\mathrm{hAPP}_{\mathrm{WT}}$ mice whereas $A \beta$ levels are much higher in $\mathrm{hAPP}_{\mathrm{FAD}}$ mice than hAPP $\mathrm{WT}_{\mathrm{T}}$ mice (Mucke et al., 2000), these findings support the hypothesis that the Reelin depletion in $\mathrm{hAPP}_{\mathrm{FAD}}$ mice is caused by $\mathrm{A} \beta$. Decreased Reelin expression was evident in the entorhinal cortex of hAPP ${ }_{\mathrm{FAD}}$ mice by $6-7$ months, although no $\mathrm{A} \beta$ deposits were found in this region at this age. Additional studies are needed to determine whether soluble nonfibrillar forms of $\mathrm{A} \beta$ (Walsh and Selkoe, 2004; Lesné et al., 2006) are responsible for altering Reelin expression in $\mathrm{hAPP}_{\mathrm{FAD}}$ mice and also in AD.

Although Reelin is also expressed in GABAergic interneurons (Fig. 1), we did not find changes in the number of Reelinexpressing interneurons in the entorhinal cortex (Fig. 2) or the hippocampus (data not shown). Therefore, the decreased levels of Reelin we detected in the hippocampus may reflect decreased release of Reelin from projections originating in the entorhinal cortex. Although additional studies are needed to elucidate why glutamatergic pyramidal cells in the entorhinal cortex are especially vulnerable to $\mathrm{A} \beta$-induced Reelin depletion, several lines of evidence suggest that this molecular alteration could have important functional consequences.

Binding of Reelin to very-low-density lipoprotein receptor/apolipoprotein E2 receptor (VLDLR/ApoER2) or integrins on the cell surface triggers intracellular molecular cascades that can influence NMDA receptor-dependent signaling pathways (Fatemi, 2005; Qiu et al., 2006). For example, binding of Reelin to VLDLR/ApoER2 recruits srcfamily kinases to phosphorylate the NR2B subunit of NMDA receptors, potentiating calcium influx through the receptors $(\mathrm{Be}-$ ffert et al., 2005; Chen et al., 2005). Such activities of Reelin are thought to underlie its ability to enhance long-term potentiation (Weeber et al., 2002) and are necessary for hippocampusdependent learning and memory (Beffert et al., 2005). By binding integrins, Reelin enhances the expression of the activityregulated cytoskeletal protein Arc (Dong et al., 2003), which is critical for LTP maintenance and memory consolidation (Guzowski et al., 2000; McIntyre et al., 2005; Plath et al., 2006; Tzingounis and Nicoll, 2006). Interestingly, hAPP ${ }_{\mathrm{FAD}}$ mice have decreased hippocampal levels of Arc and phosphorylated NR2B, as well as LTP reductions and memory impairments (Chapman et al., 1999; Palop et al., 2003, 2005; Chin et al., 2005; Kobayashi and Chen, 2005). The current study raises the possibility that decreased levels of Reelin in the entorhinal cortex and hippocam-

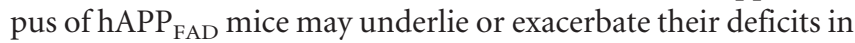
hippocampal NMDA receptor-dependent signaling, synaptic plasticity, and related cognitive functions.

For cells to respond to Reelin, they must express not only the 
A

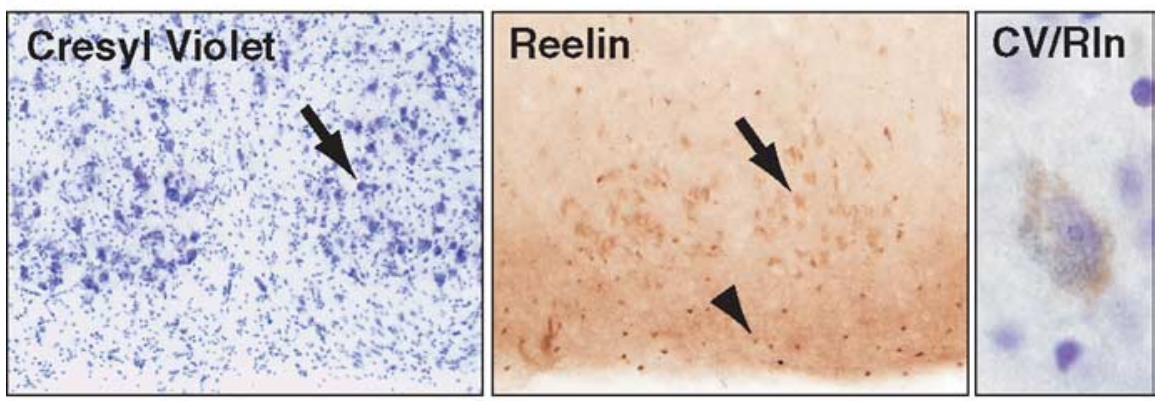

B

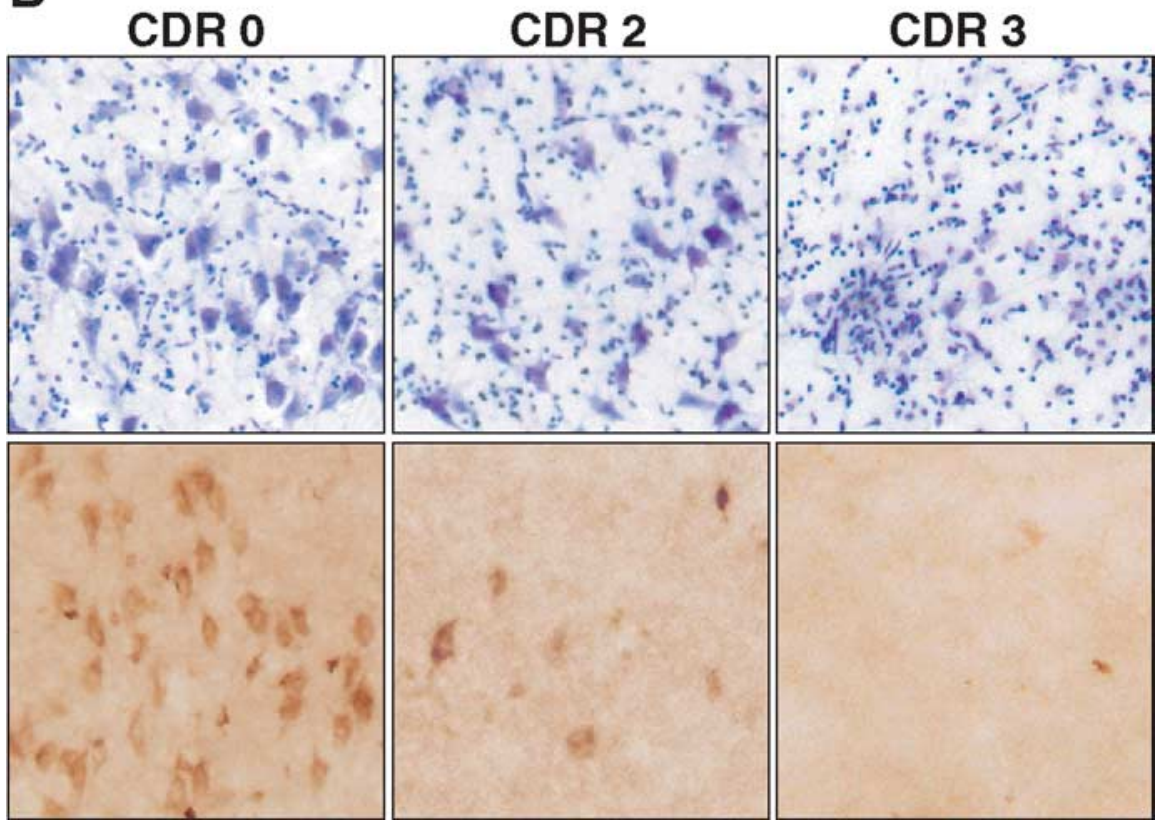

Figure 5. Reelin-expressing pyramidal neurons in the entorhinal cortex are decreased in AD. $A$, Sections from a control patient illustrating the typical distribution of pyramidal neurons in layer II of the human entorhinal cortex. Cresyl violet (CV) staining is shown on the left, Reelin (RIn) immunoreactivity in the middle, and a pyramidal neuron stained with both cresyl violet and anti-Reelin antibody on the right. Arrows point to pyramidal neurons in layer II; arrowhead points to interneurons in layer I. $\boldsymbol{B}$, Sections from humans without dementia (CDR 0), or with moderate AD (CDR 2), or severe AD (CDR 3) were stained with cresyl violet (top) or anti-Reelin antibody (bottom).

appropriate cell surface receptors but also the obligatory signal transducing protein Dab1 (Howell et al., 1997; Sheldon et al., 1997; Förster et al., 2006). Interestingly, Dab1 mRNA is expressed in layer II pyramidal neurons of the developing entorhinal cortex (Meyer et al., 2003), and we detected both Reelin and Dab1 immunoreactivities in these neurons in the adult mouse brain (data not shown). These findings suggest that Reelin may fulfill autocrine regulatory functions in the entorhinal cortex. $A \beta$-induced decreases in Reelin could disrupt this regulation and set in motion a vicious cycle that impairs neuronal functions in this brain region as well as in target regions such as the hippocampus.

\section{References}

Beall MJ, Lewis DA (1992) Heterogeneity of layer II neurons in human entorhinal cortex. J Comp Neurol 321:241-266.

Beffert U, Weeber EJ, Durudas A, Qiu S, Masiulis I, Sweatt JD, Li WP, Adelmann G, Frotscher M, Hammer RE, Herz J (2005) Modulation of synaptic plasticity and memory by Reelin involves differential splicing of the lipoprotein receptor Apoer2. Neuron 47:567-579.

Blennow K, de Leon MJ, Zetterberg H (2006) Alzheimer's disease. Lancet 368:387-403.
Botella-López A, Burgaya F, Gavin R, GarciaAyllon MS, Gomez-Tortosa E, Pena-Casanova J, Urena JM, Del Rio JA, Blesa R, Soriano E, Saez-Valero J (2006) Reelin expression and glycosylation patterns are altered in Alzheimer's disease. Proc Natl Acad Sci USA 103: 5573-5578.

Buckner RL (2004) Memory and executive function in aging and $\mathrm{AD}$ : multiple factors that cause decline and reserve factors that compensate. Neuron 44:195-208.

Chapman PF, White GL, Jones MW, CooperBlacketer D, Marshall VJ, Irizarry M, Younkin L, Good MA, Bliss TVP, Hyman BT, Younkin SG, Hsiao KK (1999) Impaired synaptic plasticity and learning in aged amyloid precursor protein transgenic mice. Nat Neurosci 2:271-276.

Chen Y, Beffert U, Ertunc M, Tang TS, Kavalali ET, Bezprozvanny I, Herz J (2005) Reelin modulates NMDA receptor activity in cortical neurons. J Neurosci 25:8209-8216.

Chin J, Palop JJ, Puoliväli J, Massaro C, Bien-Ly N, Gerstein H, Scearce-Levie K, Masliah E, Mucke L (2005) Fyn kinase induces synaptic and cognitive impairments in a transgenic mouse model of Alzheimer's disease. J Neurosci 25:9694-9703.

Dong E, Caruncho H, Liu WS, Smalheiser NR, Grayson DR, Costa E, Guidotti A (2003) A reelin-integrin receptor interaction regulates Arc mRNA translation in synaptoneurosomes. Proc Natl Acad Sci USA 100:5479-5484.

Fatemi SH (2005) Reelin glycoprotein: structure, biology and roles in health and disease. Mol Psychiatry 10:251-257.

Förster E, Jossin Y, Zhao S, Chai X, Frotscher M, Goffinet AM (2006) Recent progress in understanding the role of Reelin in radial neuronal migration, with specific emphasis on the dentate gyrus. Eur J Neurosci 23:901-909.

Gomez-Isla T, Price JL, McKeel Jr DW, Morris JC, Growdon JH, Hyman BT (1996) Profound loss of layer II entorhinal cortex neurons occurs in very mild Alzheimer's disease. J Neurosci 16:4491-4500.

Guzowski JF, Lyford GL, Stevenson GD, Houston FP, McGaugh JL, Worley PF, Barnes CA (2000) Inhibition of activity-dependent arc protein expression in the rat hippocampus impairs the maintenance of long-term potentiation and the consolidation of long-term memory. J Neurosci 20:3993-4001.

Herz J, Chen Y (2006) Reelin, lipoprotein receptors and synaptic plasticity. Nat Rev Neurosci 7:850-859.

Hiesberger T, Trommsdorff M, Howell BW, Goffinet A, Mumby MC, Cooper JA, Herz J (1999) Direct binding of Reelin to VLDL receptor and ApoE receptor 2 induces tyrosine phosphorylation of disabled- 1 and modulates tau phosphorylation. Neuron 24:481-489.

Howell BW, Hawkes R, Soriano P, Cooper JA (1997) Neuronal position in the developing brain is regulated by mouse disabled-1. Nature 389:733-737.

Insausti R, Tunon T, Sobreviela T, Insausti AM, Gonzalo LM (1995) The human entorhinal cortex: a cytoarchitectonic analysis. J Comp Neurol 355:171-198.

Kobayashi DT, Chen KS (2005) Behavioral phenotypes of amyloid-based genetically modified mouse models of Alzheimer's Disease. Genes Brain Behav 4:173-196.

Kordower JH, Chu Y, Stebbins GT, DeKosky ST, Cochran EJ, Bennett D, Mufson EJ (2001) Loss and atrophy of layer II entorhinal cortex neurons in elderly people with mild cognitive impairment. Ann Neurol 49:202-213. 
Lacor PN, Grayson DR, Auta J, Sugaya I, Costa E, Guidotti A (2000) Reelin secretion from glutamatergic neurons in culture is independent from neurotransmitter regulation. Proc Natl Acad Sci USA 97:3556-3561.

Lesné S, MT K, Kotilinek L, Kayed R, Glabe CG, Yang A, Gallagher M, Ashe $\mathrm{KH}$ (2006) A specific amyloid- $\beta$ protein assembly in the brain impairs memory. Nature 440:352-357.

Liu WS, Pesold C, Rodriguez MA, Carboni G, Auta J, Lacor P, Larson J, Condie BG, Guidotti A, Costa E (2001) Down-regulation of dendritic spine and glutamic acid decarboxylase 67 expressions in the reelin haploinsufficient heterozygous reeler mouse. Proc Natl Acad Sci USA 98:3477-3482.

Martin R, Gutierrez A, Penafiel A, Marin-Padilla M, de la Calle A (1999) Persistence of Cajal-Retzius cells in the adult human cerebral cortex. An immunohistochemical study. Histol Histopathol 14:487-490.

McIntyre CK, Miyashita T, Setlow B, Marjon KD, Steward O, Guzowski JF, McGaugh JL (2005) Memory-influencing intra-basolateral amygdala drug infusions modulate expression of Arc protein in the hippocampus. Proc Natl Acad Sci USA 102:10718-10723.

Meyer G, De Rouvroit CL, Goffinet AM, Wahle P (2003) Disabled-1 mRNA and protein expression in developing human cortex. Eur J Neurosci 17:517-525.

Morrison JH, Hof PR (2002) Selective vulnerability of corticocortical and hippocampal circuits in aging and Alzheimer's disease. Prog Brain Res 136:467-486.

Mucke L, Masliah E, Yu G-Q, Mallory M, Rockenstein EM, Tatsuno G, Hu K, Kholodenko D, Johnson-Wood K, McConlogue L (2000) High-level neuronal expression of $A \beta_{1-42}$ in wild-type human amyloid protein precursor transgenic mice: synaptotoxicity without plaque formation. J Neurosci 20:4050-4058.

Palop JJ, Jones B, Kekonius L, Chin J, Yu G-Q, Raber J, Masliah E, Mucke L (2003) Neuronal depletion of calcium-dependent proteins in the dentate gyrus is tightly linked to Alzheimer's disease-related cognitive deficits. Proc Natl Acad Sci USA 100:9572-9577.

Palop JJ, Chin J, Bien-Ly N, Massaro C, Yeung BZ, Yu G-Q, Mucke L (2005) Vulnerability of dentate granule cells to disruption of Arc expression in human amyloid precursor protein transgenic mice. J Neurosci 25:9686-9693.

Palop JJ, Chin J, Mucke L (2006) A network dysfunction perspective on neurodegenerative diseases. Nature 443:768-773.

Pappas GD, Kriho V, Pesold C (2001) Reelin in the extracellular matrix and dendritic spines of the cortex and hippocampus: a comparison between wild type and heterozygous reeler mice by immunoelectron microscopy. J Neurocytol 30:413-425.

Pariente J, Cole S, Henson R, Clare L, Kennedy A, Rossor M, Cipoloti L, Puel M, Demonet JF, Chollet F, Frackowiak RS (2005) Alzheimer's patients engage an alternative network during a memory task. Ann Neurol 58:870-879.

Pesold C, Impagnatiello F, Pisu MG, Uzunov DP, Costa E, Guidotti A, Caruncho HJ (1998) Reelin is preferentially expressed in neurons synthe- sizing $\gamma$-aminobutyric acid in cortex and hippocampus of adult rats. Proc Natl Acad Sci USA 95:3221-3226.

Plath N, Ohana O, Dammermann B, Errington ML, Schmitz D, Gross C, Mao X, Engelsberg A, Mahlke C, Welzl H, Kobalz U, Stawrakakis A, Fernandez E, Waltereit R, Bick-Sander A, Therstappen E, Cooke SF, Blanquet V, Wurst W, Salmen B, et al. (2006) Arc/Arg3.1 is essential for the consolidation of synaptic plasticity and memories. Neuron 52:437-444.

Qiu S, Korwek KM, Weeber EJ (2006) A fresh look at an ancient receptor family: emerging roles for low density lipoprotein receptors in synaptic plasticity and memory formation. Neurobiol Learn Mem 85:16-29.

Ramos-Moreno T, Galazo MJ, Porrero C, Martinez-Cerdeno V, Clasca F (2006) Extracellular matrix molecules and synaptic plasticity: immunomapping of intracellular and secreted Reelin in the adult rat brain. Eur J Neurosci 23:401-422.

Riedel A, Miettinen R, Stieler J, Mikkonen M, Alafuzoff I, Soininen H, Arendt T (2003) Reelin-immunoreactive Cajal-Retzius cells: the entorhinal cortex in normal aging and Alzheimer's disease. Acta Neuropathol (Berl) 106:291-302.

Rockenstein EM, McConlogue L, Tan H, Gordon M, Power M, Masliah E, Mucke L (1995) Levels and alternative splicing of amyloid $\beta$ protein precursor (APP) transcripts in brains of transgenic mice and humans with Alzheimer's disease. J Biol Chem 270:28257-28267.

Saez-Valero J, Costell M, Sjogren M, Andreasen N, Blennow K, Luque JM (2003) Altered levels of cerebrospinal fluid reelin in frontotemporal dementia and Alzheimer's disease. J Neurosci Res 72:132-136.

Sheldon M, Rice DS, D’Arcangelo G, Yoneshima H, Nakajima K, Mikoshiba K, Howell BW, Cooper JA, Goldowitz D, Curran T (1997) Scrambler and yotari disrupt the disabled gene and produce a reeler-like phenotype in mice. Nature 389:730-733.

Tanzi R, Bertram L (2005) Twenty years of the Alzheimer's disease amyloid hypothesis: a genetic perspective. Cell 120:545-555.

Tissir F, Goffinet AM (2003) Reelin and brain development. Nat Rev Neurosci 4:496-505.

Townsend M, Shankar GM, Mehta T, Walsh DM, Selkoe DJ (2006) Effects of secreted oligomers of amyloid $\beta$-protein on hippocampal synaptic plasticity: a potent role for trimers. J Physiol (Lond) 572:477-492.

Tzingounis AV, Nicoll RA (2006) Arc/Arg3.1: linking gene expression to synaptic plasticity and memory. Neuron 52:403-407.

van Groen T, Miettinen P, Kadish I (2003) The entorhinal cortex of the mouse: organization of the projection to the hippocampal formation. Hippocampus 13:133-149.

Verdier Y, Zarándi M, Penke B (2004) Amyloid $\beta$-peptide interactions with neuronal and glial cell plasma membrane: binding sites and implications for Alzheimer's disease. J Pept Sci 10:229-248.

Walsh DM, Selkoe DJ (2004) Deciphering the molecular basis of memory failure in Alzheimer's disease. Neuron 44:181-193.

Weeber EJ, Beffert U, Jones C, Christian JM, Forster E, Sweatt JD, Herz J (2002) Reelin and ApoE receptors cooperate to enhance hippocampal synaptic plasticity and learning. J Biol Chem 277:39944-39952. 